\title{
Ações afirmativas no Brasil e na África do Sul
}

\author{
Graziella Moraes Dias da Silva
}

Ao longo do século XX, o Brasil ea África do Sul implementaram políticas completamente diferentes, senão opostas, na definição e no tratamento das relações raciais ${ }^{1}$. Enquanto no Brasil evitou-se o estabelecimento de qualquer tipo de classificação racial formal desdeo final da escravidão em 1888, naÁfrica do Sul um regime de segregação estruturado foi mantido até 1990. 0 conceito de raça tem significados muito diferentes em cada um desses contextos: no Brasil, as fronteiras raciais são imprecisas, a segregação racial residencial é bai xa e o casamento inter-racial é comum; na África do Sul, as fronteiras raciais são mais rígidas, a segregação racial residencial é alta e o casamento inter-racial é muito raro. 0 paradoxo empírico que este artigo tenta elucidar é como e por que países com históricos tão díspares de relações raciais adotaram, no início do século XXI, políticas semelhantes para lidar com as desigualdades étnicas e raciais: ações afirmativas.

Como viajam as políticas?

D urante a década de 1990, as ciências sociais começaram a discutir como a cultura influencia o planejamento e a implementação de políticas públicas (cf. DiM aggio e Powell, 1991; Jacobsen, 1995). A mai oria desses estudos estava reagindo às teorias da escolha racional, que consideravam a política o produto direto de interesses. A percepção sociológica de quea cultura

1. Apesar de ser uma ficção biológica, utilizo o conceito de raça como um fato social no sentido clássico durkheimiano: "Todamaneira de fazer, fixada ou não, suscetível de exercer sobre o indivíduo uma coerção exterior; ou ainda, toda maneira de fazer que é geral na extensão de uma sociedade dada e, ao mesmo tempo, possui uma existência própria, independente de suas manifestações individuais" (D urkheim, 1988). 
2. “N ão as idéias, mas osinteressesmateriaise ideais governam dire tamente a conduta do homem. M uito freqüentemente, as 'imagens do mundo' criadas pelas 'idéias' determinaram, qual manobreiros, ostriIhos pelos quais a ação foi levada pela dinâmica do interesse" (Weber, 1946).

3. Para uma revisão do conceito de frames, ver Benford eSnow (2000).

4.0 sestudos baseados na teoria das instituiçõesmundiaisem geral concordam que alguns Estados-nação implementam políticas liberaisapenasformalmente, como estratégia para chamar a atenção das agências internacionais, que determinam a concessão de fundos apenasapósaimplementação dessas políticas. Em outraspalavras, o proje to das políticas édesconectado da implementação da política. Contudo, a desconexão e as estratégias de sinalização são consideradaserrosou manipulaçõesde liberadas de um sistema bem-intencionado baseado em uma cultura mundial consensual. é importante para compreender a ação social, individual ou coletiva, remonta à metáfora do manobrista de ferrovias de Weber ${ }^{2}$ eserviu como base para 0 argumento desses cientistas sociais: as crenças dos atores sociais devem ser tão centrais quanto as suas metas na compreensão da implementação de políticas.

Em uma revisão da literatura recente sobre idéias e políticas públicas, Campbell (2002) identifica diferentes mecanismos pelos quais idéias podem influenciar políticas: a mundialização da cultura (world culture), as agendas de prioridades, as estruturas cognitivas, os pressupostos normativos e os quadros interpretativos (frames) 3 . M as talvez a contribuição mais interessante dessa revisão tenha sido notar como 0 argumento cultural tem sido usado não apenas para explicar por que as políticas diferem, mas por que estão se tornando cada vez mais semel hantes. D ebates sobre as conseqüências convergentes edivergentes da globalização são apenas os exemplos mais extremos dessas polêmicas (cf. Guillen, 2001; W illiamson, 1996).

Estudos baseados na teoria de instituições mundiais (world polity) defendem 0 argumento da convergência mundial. Esses estudos concentram-se na globalização e na disseminação de uma cultura mundial (um conjunto de crenças cognitivas e normativas transnacionais), que resultaram em políticas públicas mais análogas entre si (cf. M eyer et al., 1997). O s teóricos das instituições argumentam que as estruturas legislativas e práticas de Estados-nação, em áreas como meio ambiente e direitos humanos, tornaram-se cada vez mais semelhantes - um processo definido na sociologia norte-americana como isomorfismo. No mundo contemporâneo, o isomorfismo criaria uma tendência à implementação de políticas mais liberais e individualistas. Essa tendência é explicada pela posição hegemônica dos Estados U nidos e de outras nações européias comprometidas com ideais liberal-democráticos, e pela pressão direta de agências internacionais, como as $\mathrm{N}$ ações U nidas. O s teóricos tendem a ser otimistas com relação aos progressos dos direitos humanos e concentram-se nos aspectos formais da implementação das políticas; normalmente seus modelos são fundados sobre os dados quantitativos das ratificações de acordos internacionais (cf. Strang e C hang, 1993; Wotipka e Ramirez, 2003)4.

A literatura sobre as instituições mundiais tem sido questionada por várias razões: por ser muito estruturalista, por se concentrar mais em questões metodológicas (negligenciando os mecanismos de implementação), por não levar em conta as contradições da cultura mundializada e, talvez a crítica mais central para este artigo, por não discutir os conflitos e embates 
locais durante o processo de difusão da cultura ocidental (cf. Campbell, 2002; M ittleman, 2000).

D esde a década de 1990, um número crescente de estudos tem identificado os diferentes pressupostos nacionais cognitivos e normativos, definidos de forma ampla como esquemas culturais. Esses pressupostos seriam responsáveis pelas divergências nas implementações de políticas em contextos diversos. Pesquisadores argumentam que os paradigmas de eficiência variam entre os países (cf. D obbin, 1994) eque os responsáveis pela criação de políticas tomam decisões compelidos pelas compreensões nacionais de moral ou legitimidade social, em vez de seguirem a lógica de resultados (cf. Skrentny, 1996). Em outras palavras, a implementação da política é determinada mais pelo contexto nacional do que pelas tendências internacionais. A principal crítica feita a essa linha de pensamento é que ela tende a essencializar a cultura nacional e os valores morais, e não discute como os paradigmas cognitivos e normativos são questionados e transformados (cf. Campbell, 2002).

A literatura sobre quadrosinterpretativos (frames) considera a difusão da cultura mundial e a adaptação local fatores importantes na desconexão entre as políticas internacionais e nacionais (cf. Benford e Snow, 2000). Para os sociólogos, esses quadros são conjuntos de crenças que inspiram e dão significado à ação social - influenciando o diagnóstico de uma condição social, a previsão de resultados de políticas e a motivação da ação social. N esse sentido, o quadro é "um organizador de pensamento" (Feree et al., p. 13). Ele é diferente de um pressuposto normativo: adversários políticos podem compartilhar um mesmo quadro. Por exemplo, movimentos a favor e contra 0 aborto nos Estados U nidos compartilham o mesmo quadro de direitos humanos, um defendendo os direitos das mães e outro, os direitos do feto.

U ma abordagem comparativa dos debates sobre políticas pode ajudar a identificar os quadros nacionais. A comparação permite que esses estudos analisem os conceitos que organizam os debates nacionais e que permanecem invisíveis ou essencializados. Essas diferenças tornam-se claras quando reivindicações por políticas semelhantes feitas em um contexto não têm tradução ou recepção em outros contextos.

Entretanto, a literatura sobre quadros tem sido criticada em pelo menos três aspectos. Primeiro, esses estudos normal mente não são capazes de fornecer contra-argumentos ou explicar por que outros quadros possíveis não foram considerados, fal hando, portanto, em demonstrar conexões causais. 
5.0 Icerd foi assinado por 84 países. Seu artigo 1, parágrafo 4, afirma: "N ão serão consideradas discriminação racial as medidas especiais tomadas com 0 único objetivo de assegurar o progresso adequado de certos grupos raciais ou étnicos ou de indivíduos que necessitem da proteção que possa ser necessária para proporcionar a tais grupos ou indivíduos igual gozo ou exercício de direitos humanos e liberdades fundamentais, contanto quetais medidasnão conduzam, em conseqüência, à manutenção de direitos separados para diferentes grupos raciais e não prossigam após terem sido al cançados os seus objetivos".
Segundo, eles normalmente ignoram os processos pelos quais os quadros foram construídos. Terceiro, como muitos argumentam que os atores políticos escolhem o quadro das políticas sociais de modo a satisfazer suas necessidades de legitimidade social, o discurso dos quadros pode facilmente ser classificado como estratégico e baseado em interesses, resultando em uma versão simplista da teoria da escolha racional (cf. Campbell, 2002).

Para superar essas deficiências, este artigo anal isa as disputas atuais sobre a redefinição de ações afirmativas no Brasil e na África do Sul, que denomino "disputas de enquadramento" (framing battles). A maior parte das literaturas teórica e empírica sobre quadros desconsi derou a sua natureza dinâmica. Ao discutir essas disputas, estou abordando como quadros competem entre si. A compreensão da cultura como repertório dinâmico de valores e normas, em vez de um conjunto monolítico de valores ou uma ordem moral subjacente que define as políticas, está portanto implícita na minha abordagem (cf. Lamont eT hevenot, 2000; Swidler, 1986). Além disso, uma vez que os resultados das disputas não são predefinidos, argumento que os pressupostos nacionais (neste caso, sobre fronteiras e desigualdades raciais e socioeconômicas) podem ser transformados no decorrer dessas mesmas disputas. Logo, não apenas a cultura influencia os debates sobre políticas, mas os debates sobre políticas também podem transformar pressupostos culturais.

\section{Políticas de ação afirmativa em perspectiva comparada}

As políticas de ações afirmativas são defini das de modo geral como políticas que beneficiam grupos desfavorecidos na alocação de recursos escassos, como empregos, vagas na universidade e contratos públicos. 0 documento internacional mais importante sobre a discriminação racial, a C onvenção Internacional sobre a Eliminação deTodas as Formas de D iscriminação Racial (Icerd), define políticas de ações afirmativas como medidas especiais planejadas para promover o avanço de determinados grupos raciais e étnicos ${ }^{5}$. A mai oria dos responsáveis pela criação de políticas, al guns movimentos sociais e muitos acadêmicos tendem a pressupor que as políticas de ações afirmativas estão sendo implementadas pelas mesmas razões, por meio dos mesmos processos, etêm as mesmas conseqüências (cf. Sowell, 2004; Wang, 1983). Esses estudos normalmente não são sistemáticos, ainda que baseados em dados históricos abrangentes (cf. Guillebeau, 1999; Parikh, 1997; Sowell, 1990, 2004; Wang, 1983). A falta deestudoscompa- 
rativos sobre ações afirmativas é especial mente intrigante em razão da presença de clivagens étnicas em diferentes países e da adoção cada vez mais comum dessas políticas (cf. Sabbagh, 2004).

Este artigo concentra-se nas políticas de ações afirmativas no ensino superior, que beneficiam estudantes pertencentes a grupos étnicos e socioeconômicos historicamente desfavorecidos diante de estudantes de desempenho acadêmico superior (pontuações maiores em testes de acesso a universidades ou conclusão de segundo grau em escolas melhores). N o Brasil e na África do Sul, as políticas de ações afirmativas no ensino superior visam a incluir negros e/ ou pobres, que representam a maioria da população, em universidades públicas altamente seletivas.

Ao comparar os debates atuais sobre a implementação de políticas de ações afirmativas na educação universitária no Brasil e na África do Sul, minha meta é compreender como uma política semelhante tem sido justificada em contextos diferentes.

\section{Metodologia}

N este artigo, utilizo principalmente dados qualitativos. Além de analisar documentos oficiais, realizei entrevistas no Brasil e na África do Sul entre 2005 e 2006. No caso brasileiro, analisei também dois manifestos publicados nos principais jornais em julho de 2006: um contra as cotas raciais e outro a favor (cf. Globo, 2006a; 2006b).

0 contato com a maioria dos entrevistados foi feito por meio de canais formais ${ }^{6}$. N o Brasil, realizei dezesseis entrevistas, treze com reitores, subreitores, consultores jurídicos emembros do Consel ho U niversitário de seis universidades públicas nas cinco regiões do país que adotaram as políticas de ações afirmativas (quatro faculdades federais e duas estaduais), além de dois funcionários do governo federal e um de governo estadual. $\mathrm{Na}$ África do Sul, fiz 21 entrevistas, dezoito delas com vice-chanceleres (o equival ente aos nossos reitores) e responsáveis pelo planejamento institucional ou acadêmico em seis universidades (todas administradas nacionalmente, duas historicamente brancas, duas historicamente negras e duas produtos de fusões recentes) de quatro regiões do país ${ }^{7}$. Além disso, entrevistei três funcionários do governo nacional daárea de planejamento de ensino superior ${ }^{8}$.

0 mesmo roteiro de entrevista foi usado em ambos os países, metade dele composto por perguntas abertas e a outra metade por afirmações com as quais os entrevistados podiam concordar ou não. As afirmações busca-
6. Envio desolicitações a universidades, geralmente por email, explicando o objetivo ge ral dapesquisaepedindo a indicação de nomes às secretarias e setores de planejamento institucional, admissão e desenvolvimento acadêmico.

7. A África do Sul édividida em nove províncias e realizei as entre vistas nas quatro mais populosas: Gauteng, Western Cape, Kwazulu-N atal eEastern Cape. Entre as universidades, duassão instituiçõeshis toricamente brancas, ou, na terminologia pós-apartheid, favorecidas (H AU, H istorically Advantaged Universities), duas são historicamente negras, ou defavoredidas(H DU, H istorically Disadvantaged Universities), eduasforam criadas há pouco tempo, pela fusão entre instituiç̧ões $\mathrm{HAU}$ e HDU.

8. É importanteatentar paraaquaseausênciade africanos negros entre os entrevistados (apenas dois coloureds, dois indianos e um africano). Por serem indicados por meio de canais formais, essa já é uma evidência empírica in- 
teressante. N as universidades contatadas, a maior parteinstituições historicamentebrancas, a falta de africanos negros no corpo de funcionárioséamplamente reconhecida como um problema, muito mais que no corpo discente. Em particular no nível hierárquico dealtoscargos burocráticos, ao qual sedirecionaminha pesquisa, osnegrosafricanos ainda são raros. vam medir como os entrevistados se posicionavam com relação a conceitos centrais do debate sobre ações afirmativas no mundo: diversidade, educação superior, as interações entre raça e classe. As entrevistas duraram em torno de uma ou duas horas (quarenta minutos a mais curta e duas horas e vinte minutos a mais longa).

$N$ a análisedas entrevistas, comparei não somenteasfreqüências com que os participantes concordaram ou discordaram das afirmações, como também busquei capturar as palavras-chavequeorganizavam os discursos: "ação afirmativa", "diversidade", "reparação", "inclusão social", "mobilidade social", "apartheid" e "escravidão". Além disso, identifiquei como cada uma delasfoi definida eoperacionalizada. Ao comparar as diferenças entreosdois países na freqüência de concordâncias e discordâncias referentes às afirmações, na utilização de certos conceitos e aos significados conferidos a eles, identifiquei osquadrosmaisutilizados em cada contexto nacional.

\section{Comparando Brasil e África do Sul}

U ma prolífica literatura sobre o Brasil e a África do Sul surgiu após a recente democratização dos dois países, em 1988 e 1994, respectivamente. Atualmente, o Brasil e a África do Sul são governados por partidos de esquerda, com tradição em movimentos operários e comprometidos com políticas de inclusão da população negra etrabalhadora. Ambos têm índices de desenvolvimento humano similares, taxas semelhantes de PIB per capita, altosíndices dedesi gual dadee baixosíndices de matrícula em universidades (cf. U nited Nations, 2004).

N o entanto, também existem diferenças marcantes entre os dois países: a relevância da classificação racial em políticas estatais (cf. M arx, 1998; Ribeiro, 1994, 1996), a radicalização (e racialização) de movimentos sociais (cf. Seidman, 1994), a organização de sindicatos trabal histas (cf. Schmitter, 1996; Seidman, 1994) ea transição para a democracia (cf. Friedman, 1996) são áreas em que os estudos acadêmicos identificaram divergências acentuadas. Particularmenteimportante para este estudo éo fato de raça e classe serem fortemente correlacionadas no Brasil e na África do Sul, mas interagirem de forma diferente em cada país.

$\mathrm{N}$ a África do Sul, as populações branca e negra (9,6\% e 90,4\%, respectivamente, segundo o censo sul-africano de 2001) são separadas por limites étnicos elingüísticos. 0 s brancos são divididos entre aqueles de origem britânica eosafricânderes. O snegrossão divididosem indianos, colouredseafri- 
canos $(2,5 \%, 8,9 \%$ e $79 \%$, respectivamente, segundo o censo sul-africano de $2001)^{9}$. N a população africana há diversos grupos étnicos (os maiores são os Xhosa e os Zulu) e nove idiomas oficiais. Com o inglês eo africâner incluídos, a África do Sul tem um total de onze idiomas oficiais. Entre 1948 e 1994, o Partido N acional, dominado por brancos africânderes, classificou a população oficialmente em brancos, africanos, indígenas e de cor, criando fronteiras raciais estritas em cada esfera da vida social: padrões residenciais, distribuição eorganização ocupacionais. D esdeo desmantelamento do apartheid, com a eleição, em 1994, do Congresso $N$ acional Africano (CN A), os negros, em particular os africanos, vêm ganhando cada vez mais acesso ao poder político, mas a riqueza permanece concentrada entre os brancos, e os negros estão sobre-representados entre os segmentos mais pobres.

\section{0 acesso à educação superior}

Parte das iniqüidades entre brancos e negros no Brasil ena África do Sul é atribuída ao acesso desigual à educação. 0 acesso à educação de melhor qualidade era segregado na África do Sul e muito limitado no Brasil.

$\mathrm{Na}$ África do Sul, o sistema de educação superior era dividido entre universidades brancas e negras (também divididas entre indianas, coloureds e africanas), e as primeiras contavam com muito mais recursos, sendo financiadas pelo governo nacional e por taxas escolares. Embora 0 apartheid tenha sido abolido no sistema educacional, há ainda fortes desigualdades entre as instituições educacionais historicamente brancas e negras, mesmo com um nível de financiamento nacional relativamente equilibrado ${ }^{10}$. Re centemente, o governo fundiu muitas dessas instituições para tentar romper os padrões históricos de desigual dade. Contudo, as de maior prestígio, historicamente brancas, e duas historicamente negras permaneceram separadas. $M$ etas raciais foram definidas, abrangendo os corpos docente, discente e de servidores, com o objetivo de "transformar" as universidades e assegurar a diversidade étnica e racial em todos os seus departamentos ${ }^{11}$.

N o Brasil, embora o sistema universitário nunca tenha excluído oficialmente os negros, o acesso geral à educação superior sempre foi extremamente seletivo, com os brancos tendo chances muito maiores de admissão nas universidades mais concorridas. $\mathrm{N}$ a última década, o sistema educacional superior expandiu-se no segmento privado e as universidades públicas de maior prestígio permanecem extremamente seletivas (instituições federais e estaduais com acesso gratuito aos estudantes). Ironicamente, a falta

9.0 uso de "negros" (blacks) como termo de referência para esses três grupos deriva dos movimentosanti-apartheid efoi o termo pre ferencial entreosentre vistados. D e agora em diante, os indivíduos pertencentes a essestrês grupos serão referidos como "negros" eospertencentes ao grupo de negros africanos serão referidos como "africanos".

10. No entanto, em certasáreas, o foco na produtividade acadêmica e no sucesso do estudante(taxasdeprodutividade) ainda resulta no maior acesso a financiamentos por parte das universidadeshistoricamente brancas. Além disso, como quase metadedo orçamento deriva de taxas escolares, as universidadeshistorica mente negras ficam em situação de desvantagem, uma vez que não podem cobrar muito.

11.Usei aspas em "transformar" porque setrata de um conceito central no debate político contemporâneo sul-africano. R etornarei a esseponto na discussão sobre a ação afirmativa no país. 
12. Sete são universidades federais ( $U n B$, UFPR, UFBA, UFAL, UFSP, UFPA, UFRN ) e nove são estaduais (UERJ, UNEB, UEM G, UEM S, UEL, Unicamp, Unemat, UEAM,UENF).

Em 2006, o número de universidades que adotam ações afirmativasjá se aproxima de trinta.

13. 0 primeiro estado a tornarobrigatóriaaação afirmativa nas universidadesestaduaisfoi o Rio de Janeiro, seguido por $M$ ato $G$ rosso e $M$ inas Gerais.

14. Parte da constitucionalidadedaação afirmativa focada na raça baseia-se em acordos internacionais que a apóiam. N ão é coincidência as primeiras cotas raciais no Brasil te rem sido implementadas apósaTerceiraConferência em Durban (2001), amplamentecoberta pela mídia. A tese de Peria (2004) mostra como o debateno Rio de Janeiro foi em grande parteinfluenciado pela cobertura da conferência em D urban: o projeto de lei estadual de 2001 chega a citar artigos de jornal. Além de representantes oficiais, a partir de Durban os movimentos sociaisfo- de um sistema segregado (ou a inexistência de universi dades historicamente negras) torna a baixa representatividade de estudantes de graduação negros na universidade brasileira ainda mais intensa que em países com políticas segregacionistas, como os Estados U nidos ea África do Sul.

\section{A ação afirmativa na educação superior}

Brasil

Entre 2001 e 2005, dezesseis universidades públicas brasileiras adotaram políticas de ações afirmativas, aplicadas na forma de cotas reservadas para admissão de certos grupos étnico-raciais e socioeconômicos ${ }^{12}$. Em três dos treze estados que adotaram a ação afirmativa, utilizou-se como instrumento jurídico o decreto-lei estadual ${ }^{13}$. N as outras partes do país, a decisão pela ação afirmativa ficou a cargo dos C onselhos U niversitários.

D esde a democratização, as ini ciativas de ações afirmativas são conside radas constitucionais no Brasil, tendo sido implementadas para beneficiar mulheres no sistema político e deficientes físicos no mercado de trabalho. Juízes da Suprema Corte brasileira avaliam que a Constituição de 1988 autoriza o estabel ecimento de cotas para grupos desfavorecidos (cf. Piovesan, 2006). Apesar disso, nos anos que se seguiram à implementação das cotas raciais, foram registradas trezentas ações legais contra diversas universidades que as adotaram. Alguns casos ainda estão pendentes, mas os que estão concluídos tiveram um veredicto a favor da legalidade das cotas ${ }^{14}$.

As porcentagens das cotas variaram entre 10\% e 50\%, normalmente de acordo com a distribuição étnica de cada estado. Parece haver nas políticas de ações afirmativas no Brasil a tendência a enfatizar a renda (que acabou por ser sinônimo de "classe social") em vez da, ou complementarmente à, raça. Entre as dezesseis universidades que implementaram a ação afirmativa, catorze posteriormente decidiram unir critérios socioeconômicos aos critérios raciais. Por exemplo, as universidades estaduais do Rio de Janeiro (UERJ e UEN F) criaram uma cota de $50 \%$ para estudantes provenientes defamílias de baixa renda ${ }^{15}$. A raça aparece como critério adicional: entre os estudantes selecionados de acordo com a cota social, 40\% devem ser negros. Esse foi o modelo aprovado recentemente pelo C ongresso e, se corroborado pelo Senado, se tornará obrigatório em todas as universidades federais do país. Como discutirei mais adiante, o foco primário na "classe" decorreu de uma intensa negociação. 
África do Sul

D urante o mesmo período em que o Brasil implementava políticas de ações afirmativas, a África do Sul decidia como lidar com a necessidade de "transformar" o perfil étnico e racial de seu sistema de ensino superior, particularmenteem áreas de prestígio ainda dominadas pelos brancos. N esse país, o termo "ação afirmativa" não éusado comumente no ensino supe rior. A maioria dos responsáveis pela criação de políticas prefere usar o termo "reparação" ou "transformação"16. C ontudo, as práticas são semelhantes: no processo das admissões, os estudantes pertencentes a grupos desfavore cidos (africanos, indianos e coloureds) são avaliados separadamente e metas raciais são pred efinidas para as faculdades (embora nenhuma universidade possua cotas preestabelecidas).

Como no Brasil, as políticas de ações afirmativas têm legitimidade judicial. Elas baseiam-senosprincípios descritos pela Constituição de 1996, que prevê uma "discriminação justa". O s documentos oficiais que serviram de base para as reformas recentes do ensino superior estabelecem como um dos principais objetivos a promoção de uma mai or igual dade racial em universidades (cf. Adam, 1997; Lindsay, 1997) ${ }^{17}$.

Algumas dessas práticas de inclusão de estudantes negros existiram durante 0 apartheid em universidades historicamente brancas de idioma inglês - tradicionalmente mais liberais e inclusivas ${ }^{18}$. D esde 1994, o governo nacional tem dado cada vez mais apoio, ameaçando com sanções as universidades que não atingirem uma determinada meta de distribuição racial ${ }^{19}$. $M$ ais de dez anos após o final do apartheid, o número de estudantes africanos e negros aumentou consi deravelmente em instituições brancas. Entre tanto, eles continuam a apresentar menores taxas de graduação eestão concentrados em departamentos de menor prestígio. Além disso, como o ensino superior na África do Sul não é gratuito, o apoio financeiro a estudantes negros encontra-se no centro do debate. As políticas de financiamento têm de garantir 0 acesso aos estudantes de baixa renda, em geral os africanos, mas 0 orçamento para empréstimos e bolsas ainda é muito baixo. 0 crescimento do número de estudantes negros aliado à exclusão econômica da população mais pobre levanta uma questão análoga à do caso brasileiro: 0 foco deve mudar da raça para a classe? ram convidadosaparticipar, o queforçou o governo a aceitar o proble mada discriminação ra cial. Paraa descrição dos debates, consultar o capítulo2 deTelles(2004).

15. O s critérios para a determinação do status socioeconômico são rendafamiliar (cercadeseiscentosreaisou menos) e ter feito os três anos do ensino médio em uma escola pública.

16. Diferente do Brasil, o núcleo do debate sobre ação afirmativa na África do Sul tem sido o mercado de trabalho, o chamado "Black Economic Empowerment" (BEE, Capacitação Econômica dos N egros).

17. Contudo, uma das razõesapresentadaspor um dos entrevistados para não usar o conceito de ação afirmativa para definir a política das universidades era 0 medo de que o termo remetesse a uma história complexa de bataIhas jurídicas nos Estados Unidos.

18. Embora nunca tenha adotado o sistema decotas, aU niversity of CapeTown (UCT) foi uma das pioneiras em políticas de ações afir- 
mativas para estudantes negros, mesmo antes do final do apartheid. D esde 1980, implementou um programa de desenvolvimento acadêmico, co-financiado por patrocinadores externos. Em 1994, criou também um programa de pesquisa com admissão alternativa, em que os estudantes negros complementavam suasnotascom um teste de aptidão (cf. M abokela, 2000).

19. Aspolíticasno ensino superior também se concentraram na fusão de universidades previamente segregadas e na "transformação" de instituições historicamente brancas (cf. Subotzky, 2003).
Por que Brasil e África do Sul estão implementando ações afirmativas?

As respostas tradicionais ao porquê de Brasil e África do Sul terem implementado políticas de ações afirmativas, para o bem e para o mal, são a modernização e a globalização (cf. Bourdieu e Wacquant, 1999; Subotzky, 2003; Telles, 2004). 0 Brasil e a África do Sul passaram recentemente por processos de democratização. Em 1989, foi decretado o fim do período de vinte anos de ditadura militar no Brasil, e um ano depois, na África do Sul, $\mathrm{N}$ elson $\mathrm{M}$ andela saiu da prisão, dando início ao período detransição democrática. A modernização explica-se porque, ao se tornarem democracias, esses dois países passaram a sofrer pressão de grupos sociais para compensar suas dívidas históricas com grupos excluídos (cf. Telles, 2004).

A teoria das instituições também utiliza parcialmente a explicação da modernização, segundo a qual a ação afirmativa é uma questão de direitos humanos. A modernização e a democratização desempenham função importante nesse modelo, que é o de abrir espaço para que os movimentos sociais (advocacy groups) pressionem por determinadas políticas. A teoria enfatiza influência de agências internacionais que, ao apoiarem e reivindicarem determinadas políticas e direitos sociais, ajudam a difundir a cultura da igualdade e dos direitos humanos (cf. M eyer et al., 1997; Telles, 2004).

A influência da tercei ra conferência das $\mathrm{N}$ ações U nidas contra o racismo e a discriminação, em 2001, em D urban (África do Sul), na implementação das políticas deações afirmativasno Brasil indica a relevância dessa hipótese. D iversos grupos ligados aos movimentos negros usaram a conferência para denunciar a existência de discriminação racial no Brasil, forçando o Estado brasileiro a aceitar a denúncia ea propor políticas para combatêla (cf. H tun, 2004). D a mesma forma, no caso daÁfrica do Sul, o mundo estava atento ao modo pelo qual o C N A lidaria com as desigualdades descomunais herdadas do apartheid (cf. Subotzky, 2003). As políticas deações afirmativas surgiram como uma resposta legítima, apoiadas pelas agências internacionais.

Raciocínio semelhante, todavia, vêa adoção da ação afirmativa de forma mais pessimista. Assim, a pressão internacional por ações afirmativas élida como imposi ção das agências internacionais. Bourdieu e Wacquant (1999) sustentam que a demanda por políticas raciais no Brasil é uma forma de violência simbólica, argumentando que agências liberais, como a Fundação Ford, estariam impondo categorias raciais norte-americanas à agenda de pesquisas dos acadêmicos brasileiros, ou seja, exportariam as suas próprias compreensões de relações raciais e direcionariam as políticas públicas com 
base nessas categorias ${ }^{20}$. Portanto, mais uma vez, estaria ocorrendo a difusão internacional dessas políticas, agora, porém, vista como geradora de um impacto negativo.

Embora esteja claro que a globalização e a difusão das políticas tenham algo a ver com a aplicação de políticas de ações afirmativas no Brasil e na África do Sul, persiste a dúvida de se tal implementação significa ou não a mesma coisa nos dois países. O u seja: ações afirmativas têm o mesmo significado nesses dois contextos? A difusão gera necessariamente isomorfismo? Essas questões são exploradas no restante do artigo.

Tipologia dos quadros e das disputas de enquadramentos

Ao analisar as entrevistas no Brasil e na África do Sul, identifiquei quatro quadros interpretativos de ação afirmativa: diversidade, capital humano, reparação e inclusão social. Esses quadros não aparecem de forma homogênea nos dois países e podem estar em contradição entre si. A seguir, apresento e discuto rapidamente cada um deles e como se relacionam. De pois, volto à análise de como esses quadros são interpretados e como se dá a disputa entre eles em cada país.
20.Apesar de eu não ter encontrado trabaIhos acadêmicos com argumentos semelhantes na África do Sul, nota-se entre os subreitores universitários desse país uma resistência em denominar as suas políticas como ações afirmativas por considerarem-nas características das políticas norte-americanas.

\section{Tipologia dos quadros}

\begin{tabular}{|c|c|c|c|c|}
\hline QuAdRos & DIVERSIDADE & CAPITAL HUMANO & REPARAÇÃo & INCLUSÃO SOCIAL \\
\hline JUSTIFICATIVA & $\begin{array}{l}\text { Estudantes de origens dife- } \\
\text { rentes devem ser incluídos: } \\
\text { multiculturalismo }\end{array}$ & $\begin{array}{l}\text { N ecessidade de identificar ta- } \\
\text { lentosnão aproveitados por } \\
\text { deficiências do mercado } \\
\text { (market failure) }\end{array}$ & $\begin{array}{l}\text { Grupos étnicos discrimina- } \\
\text { doshistoricamente devem } \\
\text { ser compensados }\end{array}$ & $\begin{array}{l}\text { G rupos desfavorecidosno pre- } \\
\text { sentedevem receber tratamen- } \\
\text { to especial }\end{array}$ \\
\hline Metas Formais & $\begin{array}{l}\text { M elhoria das relações raciais } \\
\text { equebra deestereótipos raciais }\end{array}$ & $\begin{array}{l}\text { Crescimento edesenvolvi- } \\
\text { mento econômicos }\end{array}$ & $\begin{array}{l}\text { Compensação einclusão } \\
\text { social }\end{array}$ & $\begin{array}{l}\text { Criação deoportunidades para } \\
\text { mobilidadee inclusão social }\end{array}$ \\
\hline
\end{tabular}

\section{Diversidade}

Alguns defendem as políticas de ações afirmativas no ensino superior com base na idéia de que a diversidade é um interesse de bem comum para a qual idade da educação epara a integração do país. Logo, ter estudantes de diferentes origens raciais e étnicas enriqueceria as experiências de aprendizado na universidade e poderia contribuir para a construção de uma socie- 
dade menos dividida racialmente. Além disso, a necessidade de promover a ação afirmativa é compreendida como a necessi dade de fazer todos os estudantes entenderem as diferenças culturais, aprenderem a adotar perspectivas de indivíduos de origens diferentes e interagirem em ambientes diversificados. A sobreposição entre raça e cultura éum pressuposto freqüente (cf. H ollinger, 1995).

\section{Capital humano}

O utros baseiam seus argumentos no fato de que deficiências do mercado, causadas por discriminação racial esocioeconômica, podem resultar em desperdício de recursos humanos. 0 país não aproveita recursos humanos importantes se um grupo étnico ou racial estiver sendo sistematicamente excluído (cf. Becker, 1957). 0 desperdício de capital humano podedificultar o crescimento econômico, porque em uma sociedade tecnológica os talentos individuais são essenciais para a inovação. A deficiência do mercado, no caso da universidade, decorre da imprecisão dos procedimentos de admissão. Para evitar o desperdício, os processos de seleção devem adotar medidas alternativas à meritocracia para identificar talentos individuais no grupo desfavorecido.

\section{Reparação}

A ação afirmativa podetambém ser defendida como uma compensação necessária por uma discriminação ocorrida no passado. Escravidão e apartheid, no Brasil e na África do Sul, respectivamente, proporcionam justificativas históricas para a compensação (cf. H amilton et al., 2001). Esse quadro implica o direito histórico dos negros como grupo.

\section{Inclusão social}

Finalmente, pode-se justificar a ação afirmativa pela necessi dade de fechar as atuais lacunas ao acesso a recursos. Diferentemente da justificativa da reparação, que utiliza a discriminação histórica como argumento principal para a compensação atual, ao utilizar-se o quadro de inclusão social de fende-se que a ação afirmativa seja necessária para promover a mobilidade de grupos excluídos socialmente. Em outras palavras, éa discriminação racial ou de classe do presente, e não a discriminação do passado, quejustifica a 
ação afirmativa. U ma vez que a justificativa da inclusão social concentra-se nas desigualdades socioeconômicas, negros de classe média podem ser excluídos dessas políticas.

\section{Disputas de enquadramento no Brasil e na África do Sul}

Brasil

$\mathrm{N}$ as entrevistas nas universidades brasileiras, os quadros mais usados para justificar as políticas de ações afirmativas são o da inclusão social e o da diversidade. A reparação é menos freqüente e o capital humano está praticamente ausente do debate.

Trata-se, em grande medida, de uma disputa entre as perspectivas particularista e universalista, entre ter como alvo a classe ou a raça nas políticas sociais. Contudo, há também uma disputa menor entre individualistas e coletivistas, traduzida na forma de um debate sobre o significado de incluir estudantes negros em universi dades públicas: trata-se exclusivamente de inclusão social deum grupo excluído ou estamosfalando de dar voz a estudantes negros?

N o Brasil, a justificativa principal para a ação afirmativa é criar chances de mobilidade para grupos desfavorecidos em uma sociedade de alta desigualdade por meio do ingresso na universidade pública. Isso fica claro pela quase total idade dos entrevistados brasileiros concordarem com afirmações como "a meta da ação afirmativa écriar oportunidades de mobilidade social para grupos desfavorecidos"; "o papel principal da universidade pública é aceitar estudantes quenão podem pagar universidades privadas"; e "a distribuição de estudantes em universidades públicas deve corresponder ao perfil racial e socioeconômico da população".

A princípio, como resultado da Conferência de D urban, que deu origem ao debate sobre o sistema de cotas no Brasil, o foco da ação afirmativa era a inclusão de estudantes negros nas universidades públicas. As estatísticas apresentadas na conferência mostraram que os estudantes negros estavam ausentes nos departamentos mais seletivos das universidades públicas, apesar de serem quase a metade da população. Em 2002, logo depois da conferência, o estado do Rio de Janeiro decidiu pela obrigatoriedade de cotas para estudantes negros $(20 \%)$ e para estudantes oriundos de escolas públicas (25\%); a U niversidade Estadual da Bahia também estabeleceu cotas para estudantes negros vindos de escolas públicas. No ano 
seguinte, duas universidades federais criaram cotas somente para estudantes negros, e outras universidades estaduais estipularam cotas para estudantes negros de baixa renda.

D ois aspectos devem ser observados nesse momento inicial. Primeiro: a ação afirmativa assumiu a forma de cotas efoi estabelecida logo após a conferência (cf. Peria, 2004). Segundo: as cotas raciaisforam rapidamentecombinadas com as cotas socioeconômicas.

D eacordo com os entrevistados que utilizam a inclusão social como quadro, as cotas são necessárias porque a desigual dade brasileira étão intensa e estrutural que apenas o mérito não é suficiente para reverter o quadro. Todos os entrevistados revelaram-se céticos quanto ao valor dos testes de seleção como medida demérito eargumentaram que, sedepender somentedesse tipo de critério, as universidades estariam reproduzindo as desigualdades socioeconômicas:

É a questão da democratização do acesso, não é? Porque as universidades públicas no Brasil, sobretudo as federais, elas foram atendendo, cada vez mais, as elites, elas foram atendendo, cada vez mais, a elite pelo fato de seus vestibulares serem mais difíceis; um índice de concorrência muito alto; e chegou-se a um ponto em que basicamente os alunos das universidades públicas, sobretudo as federais, naqueles cursos de maior prestígio social, eram estudantes provenientes de escolas privadas e estudantes de alto poder aquisitivo. Então, isso é um ponto para reflexão que foi considerado, evidentemente, na adoção de políticas de ação afirmativa. N essa sociedade desigual [...] a universidade mantida pela própria sociedade teria o papel de democratizar 0 acesso, dando um retorno à sociedade que a mantém e a sustenta.

U ma pesquisa recentefeita com as elites brasileiras revel ou que as classes privilegiadas consideram a pobreza ea desigual dade a segunda maior ameaça à democracia e ao desenvolvimento brasileiros, ficando atrás apenas do baixo nível de escolaridade da população (cf. R eis e M oore, 2005).

A mesma pesquisa, todavia, mostrou que essas elites são contra qualquer tipo de ação afirmativa voltada para mulheres e grupos raciais e étnicos, argumentando que isso equivaleria à discriminação de grupos "nãominoritários", ou seja, as elites rejeitam argumentos de diversidade e de reparação. A adoção do primeiro sistema de cotas pelas universidades teve uma grande repercussão na imprensa (cf. Fry e M aggie, 2002). As cotas para estudantes pobres, no entanto, não foram fortemente questionadas. $A$ 
adoção das chamadas "cotas sociais" tornou-se a solução. A combinação de raça e classe na categoria de "desfavorecidos" sustenta esse discurso.

D e acordo com o quadro de inclusão social, a exclusão de negros normalmente aparece como um problema socioeconômico, e se apóia na vinculação de raça eclasse. $\mathrm{N}$ egros devem ser ben eficiados pela sua exclusão aos recursos socioeconômicos: renda, educação e empregos. Contudo, em um país com tanta desigual dade como o Brasil, não são apenas os negros os excluídos, portanto há a necessi dade de incluir outros segmentos da população. Com isso, a especificidade da questão racial perdeu-se no debate ea maioria das pessoas começou a argumentar que seria melhor considerar apenas os indicadores sociais, pois os dois tipos de cotas tinham a mesma meta: diminuir a desigual dade social. Portanto, o foco deveria ser socioeconômico, como ressaltou uma entrevistada.

[N ós decidimos] trabalhar com a idéia de que os estudantes da rede pública e os estudantes negros, principalmente estes dois grupos, que detêm o maior percentual de cotas, que entre eles há distinções, e dentre eles a instituição optou por lidar com os estudantes mais carentes. [... ] N ão bastava ser negro, tinha que ser, necessariamente, carente; esses [brancos e carentes] ficavam de fora das cotas, eles concorrem às vagas habituais, às vagas não reservadas [...], dá pra compreender? 0 que a gente busca é resgatar aquele espírito primeiro de uma lei de política afirmativa que precisa, efetivamente, ser um mecanismo de migração entre classes sociais; senão não tem sentido você ter a lei.

As tensões entre as cotas social e racial ficam bastante evidentes na de claração abaixo, de um sub-reitor de graduação que implantou o sistema de cotas pela primeira vez recentemente, no vestibular de 2005. Segundo ele, as cotas nunca teriam sido aprovadas se fossem apenas raciais:

U ma outra questão importante era o seguinte: al gumas pessoas concordavam e concordam, mas não concordavam e continuam não concordando com a questão da cor, eu ouvi isso agora no telefone, que a inclusão da escola pública, muito bem, mas a questão da cor não seria adequada; há pessoas, inclusive importantes, negras, que também acham que isso pode ser problemático. $M$ as foi argumentado aqui pelos representantes dos movimentos e nós nos convencemos. Sim, e a universidade também sempre disse que uma cota somente de cor não aconteceria, pelo menos nós como representantes da administração, as pessoas que estavam no grupo e eram representantes da administração, que isso nós não defenderíamos. 
Então, o que acabou acontecendo foi o seguinte: a cota tem um registro de cor, mas as porcentagens são, praticamente, as porcentagens da escola pública no estado [...]. Assim, tanto quanto é possível medir em porcentagem, não há discriminação [...] há caracterização de branco e negro nas cotas, mas não há desvantagem ou vantagem para um e para outro. Então, nesse caso a questão da cor ficou como registro: como o país historicamente excluiu por cor, a universidade [quer] claramente falar que está incluindo por cor. M as na prática, mesmo, as cotas são realmente sociais.

Essa longa citação exemplificamuitas das tensões queapresento nesteartigo: a resistência de certos grupos a aceitarem o debate racial no Brasil, a pressão do movimento negro para que seja mantido o foco na raça, astensões entre a discriminação no passado e no presente (o país historicamente excluiu por raça, mas eleainda exclui?), ea predominância do quadro deinclusão social, com a adoção de cotas sociais. Embora identidades raciaisfaçam parte da questão social, as cotas sociais no Brasil parecem fazer referência apenasàrenda.

O sentrevistados que defenderam cotas raciais exclusivas, ou em conjunto com cotas para pessoas de baixa renda, apresentaram dois argumentos: 0 primeiro, mais comum, afirma que os mecanismos da exclusão racial são diferentes dosmecanismosda exclusão socioeconômicae, portanto, devem ser tratados deforma diferente. Elesargumentam a partir do quadro da inclusão social, mas entendem raça como categoria diferente de classe. Como disseram os entrevistados de universidades queadotaram cotas raciais exclusivas:

Eu acho que você pode ter os dois tipos de ações afirmativas [socioeconômica e racial], ou separadas ou conjuntamente. Agora, um substituir o outro, eu não acredito nisso, não, porque a discriminação no Brasil opera do ponto de vista da raça; não é do ponto de vista econômico; ela opera do ponto de vista da raça; e também opera do ponto-de-vista econômico, mas não é só o econômico.

Essa pessoa, autodeclarada negra e ativista do movimento, apóia cotas puramente raciais, mesmo que complementadas por cotas socioeconômicas. 0 utros entrevistados brancos também defendem essa perspectiva. 0 argumento mistura os quadros de inclusão social, reparação e diversidade, fundamentando-os em termos particularistas, já que os negros (pretos e pardos) devem ser beneficiados para ter chances de inclusão social. O s negros são excluídos porque são negros, não porque são pobres, e portanto há 
um aspecto particular aos negros que deve ser abordado por políticas sociais. A justificativa é que os negros são mais excluídos do que os brancos por serem discriminados, independentemente de sua origem social, portanto o mesmo quadro de inclusão social éusado para defender políticasfocadas em raça. 0 objetivo é a inclusão social dos negros como coletividade. Se necessário, podem ser estabelecidas cotas sociais, mas separadas. Como de clarou um dos entrevistados, os negros ricos também sofrem discriminação e têm sido estigmatizados por estereótipos raciais, e serão eles os maiores perdedores se as cotas contemplarem apenas os indivíduos de acordo com a sua origem socioeconômica.

0 segundo argumento a favor de cotas puramente raciais é uma versão mais pura do quadro da diversidade, que questiona a junção de raça e classe com base em um raciocínio diferente: de acordo com os seus defensores, as políticas de ações afirmativas são necessárias para quea identidade racial seja repensada no Brasil. O s estudantes negros que ingressam na universidade levam as própriasquestões eidentidades paraa sala deaula. Segundo umadas entrevistadas (que se declarou espontaneamente negra), ao falar sobre a necessidade degarantir que osestudantes negros desenvolvam sua identidade:

0 programa [diversidadena universidade] foi desenhado como um aumento quantitativo - dos alunos negros nas universidades - e entendo que esse aumento vai mexer com algumas estruturas. 0 que a gente pensa é que só isso não... Q ue 0 aluno tem que entrar, 0 aluno do PIC tem que entrar mais com a consciência da sua identidade, com a consciência do processo de desigualdade que ele sofre, para se afirmar positivamente. É um ambiente de muito poder, poder simbólico, evidentemente, éum ensino voltado para o ponto de vista ocidental, éaté um ponto de vista que nega as origens do estudante negro. A língua culta, a norma culta, toda uma postura que os alunos que vêm desses prévestibulares, que são negros, não têm. Ele acaba sendo excluído. Então, se eles não tiverem uma base de entendimento do que isso significa, ele entra na universidade, como muitos dizem, negro e sai branco. Porque sai muitíssimo educado e já totalmente desvinculado do seu local de origem. Então, o nosso investimento e as nossas ações também se voltam muito para isso. À medida que ele tem consciência da sua negritude e do seu projeto de exclusão, e entende isso não como uma forma de se diminuir, mas de se potencializar ainda mais, altera o processo de conhecimento.

Em suma, de acordo com o quadro interpretativo da diversidade, a meta da ação afirmativa não seria apenas melhorar osíndices socioeconômicos da 
população negra, mas também reforçar a identidade negra e aumentar a consciência da discriminação e da desigual dade raciais. Para que isso aconteça, os estudantes devem asseverar as suas identidades. Em outras palavras, cultura e raça se sobrepõem, e os indivíduos negros devem ser incluídos porque são capazes de contribuir com uma perspectiva racial específica.

A gente não está discutindo só quem vai ter acesso à vaga; a gente está discutindo a recomposição das identidades coletivas nesse país; a gente está rediscutindo nesse país o que é ser branco, o que não é; são discussões que, ao largo da nossa história, nunca estiveram na cena pública. [...] Então, [ao juntar raça e classe] essa oportunidade está sendo perdida e muito por conta da atuação de nossos setores progressistas de esquerda, brancos, que não assumem de maneira nenhuma, porque isso questiona a segurança ontológica deles, o lugar que eles ocupam na sociedade, então é uma oportunidade que se está perdendo.

Como no caso do entrevistado citado acima (autodeclarado negro e ativista do movimento negro), a diversidade como valor éexigida com mais intensidade pelo movimento negro, que a considera insuficientemente ressaltada pel os discursos das políticas. Todos os que mencionaram a diversidade são negros, a maioria jovem e militante.

U ma das possíveis razões pela qual a diversidade sofre tanta resistência no Brasil éa falta de fronteiras culturais mais definidas entre negros e brancos no país. As fronteiras raciais em si são imprecisas devido ao grande número de uniões inter-raciais e às classificações de raça baseadas na cor. Essa fluidez das frontei ras culturais pode ser explicada de uma perspectiva histórica. A colonização ibérica voltou-se mais para a assimilação étnica e cultural do que a francesa, o que a coloca em oposição à colonização inglesa, quemanteveas divisões étnicas existentes ou emergentes (cf. M arx, 1998). Essas diferenças de estratégias de colonização também ficam evidentes pela comparação das relações raciais entre países africanos, por exemplo: M oçambique e Angola versus África do Sul e Zimbábue (cf. Fry, 2000; 2005). N ão é desprezível o fato de que, inicialmente, todos os países que implementaram políticas de ações afirmativas sejam ex-colônias britânicas (Índia, Sri Lanka, Estados U nidos, M alásia, N igéria).

A concep ção do Brasil como democracia racial originou-se na década de 1930 e foi essencial na adoção de políticas que val orizaram a herança miscigenada brasileira. Segundo essa ideologia, a mistura de raças deveria ser positivada em vez de estigmatizada. O s símbolos negros e africanos torna- 
ram-se nacionais: a feijoada, o samba e até mesmo al gumas práticas religiosas. I sso acontecia ao mesmo tempo em que, nos Estados U nidos e na África do Sul, as políticas governamentais segregavam negros em determinados bai rros e regulamentavam os casamentos inter-raciais.

D e acordo com Telles (2004), as desigualdades raciais horizontais no Brasil (segregação racial em casamentos, padrões residenciaise redes deamizade) não são tão fortes quanto as desigual dades raciais verticais (mercado de trabalho, educação, exclusão social). I sso poderia explicar por que, no Brasil, negros e brancos parecem ser fortemente divididos pelas fronteiras econômicas- usadas parajustificar a definição de pretose pardoscomo negros-, e não tanto pelas culturais (cf. Lamont eBail, no prelo). As baixas desigualdades horizontais desafiam a diversidade como quadro, em contraste com a inclusão social.

No manifesto contra as cotas raciais publicado em junho de 2006, a idéia de transformar classificações estatísticas em identidades raciais é vista como um grande perigo. Segundo um dos entrevistados (negro): "A idéia de diversidade é percebida como uma ameaça, criadora de conflito". I ronicamente, nesse mesmo manifesto argumenta-se que a diversidade deve ser apoiada como "um processo vivaz eintegrante do caminho de toda a humanidade" (Globo, 2006a), ou seja: diversidade é redefinida como assimilação. M esmo o manifesto a favor das cotas - também publicado em junho de2006 - enfraquece os argumentos a favor da diversidade, concentrandose em argumentos de inclusão social e de reparação.

o quadro da reparação aparece logo no início do manifesto a favor das cotas: "A desigualdade racial vigentehoje no Brasil tem fortes raízes históricas e esta real idade não será alterada significativamente sem a aplicação de políticas públicas dirigidas a esteobjetivo" (Globo, 2006b). D eacordo com um dos entrevistados (negro), o Brasil nunca ter tido uma política racial desde o final da escravidão éo que torna um sistema de cotas desse tipo tão importante:

Então, quer dizer, é um dado gritante como é que em cem anos, mais de cem anos, de extinção da escravidão não houve por parte do Estado brasileiro nenhuma preocupação, muito menos políticas públicas de integração, de integração da população negra nos aspectos formais da evolução social, digamos assim, educação, mercado de trabal ho, nas condições de vida em modo geral, né? Ao contrário dos Estados U nidos, por exemplo, onde houve políticas públicas e você sabe disso; apesar de alguns ainda... as pessoas ainda fazem esse tipo de comparação: 
21. Partes dadeclaração desse entrevistado sobre a origem das universidades negras podem ser questionadas, uma vez que a maioria das universidades negras, concentradas no Sul do país, foram criadasparaquenegrosnão freqüentassem universidades brancas - dentro dalógicado "separados mas iguais" (Jim (row segregation) vigente nessa região na primeira metade do sé culo XX. Por outrolado, é verdade que essas políticas permitiram aos Estados Unidoster um número deprofissionais eintelectuaisnegrossuperior ao do Brasil.
"Quem é mais racista, o Brasil ou os Estados Unidos?". U m acha que é um e outro acha que é outro, um é mais explícito, outro é menos explícito, enfim, acho que racismo é racismo, é tudo a mesma coisa, acho que um não é mais ou menos do que outro, né? M as nos Estados Unidos, por exemplo, você sabe disso, evidentemente, teve políticas de integração, a criação... as mais de cem universidades negras que existem hoje nos Estados Unidos começaram logo após a abolição, com escolas, pequenas escolas financiadas pelo estados norte-americanos, do N orte sobretudo. Aqui no Brasil não houve nenhum tipo de política de integração, nenhum, você pode percorrer a legislação brasileira de cabo a rabo, do século XIX pra cá, não houve nenhum tipo de inclusão de populações negras²1.

Contudo, a reparação não aparece como um quadro central nas entrevistas. M esmo no manifesto a favor das cotas, o principal argumento deriva da inclusão social: "Foi a constatação da extrema exclusão dosjovensnegros e indígenas das universidades públicas que impulsionou a atual luta nacional pelas cotas" (Globo, 2006b).

Identifico três explicações possíveis para a falta de centralidade da reparação, como quadro, no Brasil. Primeiro, o fato de nenhuma política formal para excluir os negros ter sido implementada após a abolição. Em outras palavras, desdeo fim da escravidão a cidadania política no Brasil não foi condicionada à raça - como sustenta o discurso republicano. Como argumenta o manifesto público de intelectuais contra as cotas raciais, publicado nos principais jornais brasileiros:

0 princípio da igualdade política e jurídica dos cidadãos éum fundamento essencial da República, é um dos alicerces sobre o qual repousa a Constituição Brasileira [...]. A verdade amplamente reconhecida é que o principal caminho para 0 combate à exclusão social é a construção de serviços públicos universais de qualidade nos setores de educação, saúde e previdência, em especial a criação de empregos. Essas metas só poderão ser alcanç̧adas pelo esforço comum de cidadãos de todos os tons de pele contra privilégios odiosos que limitam o alcance do princípio republicano da igualdade política e jurídica (Globo, 2006a).

Segundo, os altosíndices de miscigenação eas fronteiras raciaisimprecisas dificultam a determinação de quem é descendente de escravos: de acordo com uma pesquisa no estado do Rio de Janeiro, $37 \%$ dos brancos declararam ter ascendentes negros, enquanto $80 \%$ dos pardos e $59 \%$ dos pretos declararam ter descendentes brancos (cf. Telles e Bailey, 2002). Além disso, 
no final da escravidão no Brasil muitos negros já estavam livres e eram donos de escravos. Em suma, a raça no Brasil é definida por um misto de cor da pele e status socioeconômico, e não por regras de hipodescendência (one drop rule). Portanto, decidir quem deve ser beneficiado por políticas raciais com base no argumento da reparação pela escravidão pode ser problemático: as pessoas de pele branca podem ser incluídas se provarem que seus ancestrais eram negros?

Por fim, temos o argumento de que, se as desi gualdades atuais são resultantes da discriminação do passado, não há discriminação no presente. Essa oposição entre discriminação no presente e no passado tende a reforçar 0 quadro de inclusão social, como exemplifica esta citação:

E também o perfil racial corresponde a um perfil social, não é? A gente sabe que os negros são os mais pobres porque historicamente foi assim constituído esse segmento racial, e isso, de certa maneira, se manteve. Então, você dando acesso, democratizando o acesso, dos mais pobres à educação superior, de certa maneira você está também contemplando essa... a redução das desigualdades que estão postas no âmbito racial.

0 último traço interessante das disputas brasileiras só é perceptível em comparação com a África do Sul: a falta do capital humano como quadro. H ouve apenas uma menção nas entrevistas sobre o papel da universidade na geração de crescimento econômico ou na identificação de talentos individuais. I sso se deve, provavelmente, à desconexão entre universidadeemercado no Brasil. As universi dades públicas têm orçamentos garantidos e são consideradas historicamente as melhores do país. Além disso, elas são gratuitas e estão praticamente isentas de pressão por desempenho.

A meta do discurso da inclusão social parece ser uma parte mais central das discussões nas universidades públicas brasileiras, muito mais que a meta da produção de conhecimento de ponta, pelo menos em algumas regiões. Há um consenso entre os entrevistados de que as universidades públicas devem se expandir para receber mais estudantes, ao contrário da tendência histórica de ampliação do ensino superior pelo fomento ao setor privado. A ação afirmativa é vista como uma maneira de garantir que indivíduos de baixa renda e negros tenham acesso às universidades públicas gratuitas ${ }^{22}$.

Em resumo, no Brasil, as disputas pela ação afirmativa parecem resultar na transformação da política baseada em raças em políticas mais universalistas
22. Praticamente não houve menções nas entrevistasbrasileirasà eficiência (somente em três de doze) ou à alta taxa de não-conclusão que caracterizam essas instituições (cerca de 40\%). Tampouco os custos dessa expansão foi levado em conta. 0 fator do isolamento do idioma (a academia escreveeensinaem português) podetambém tornar as universidades brasileiras menos competitivasno mundo acadêmico internacional. 
com foco no status socioeconômico. Essa transformação parece adequar-se à compreensão brasileira da desigual dade como puramente socioeconômica e à necessidade de manter o ideal de assimilação. 0 uso da inclusão social combina os problemas da população negra com os problemas do grande contingente de brancos pobres. Contudo, os debates em torno de políticas de ações afirmativas foram instigados pelo movimento negro, que deflagrou uma discussão intensa sobre as desigualdades raciais no Brasil:

$\mathrm{N}$ a verdade uma das... questões dessa discussão é importante, se referir a cor ou não se referir a cor. Isso é um debate com várias nuances, com vários aspectos, tem aquela coisa que eu falei, tem pessoas, inclusive negras, importantes, que temem o que pode resultar disso e tal. M as faz parte, também, da nossa história que as pessoas tentem ser o mais brancas possível, então todo mundo que de alguma forma consiga disfarçar se dizia branco. Então, com essa discussão que tem acontecido pelo país... é uma situação hoje muito diferente do que seria dez anos atrás; por exemplo, hoje um número muito maior de pessoas se diz, facilmente, mestiço. 0 ideal seria que ninguém precisasse ficar se preocupando com isso; mas antes existia a preocupação de se dizer branco, e continua havendo, claro; mas um número maior de pessoas se permite e alguns têm orgulho de dizer mestiço. Eu acho que quem pensa, quem sabe o que aconteceu no país, tem que falar que a exclusão de cor existe mesmo, tem que falar que isso existe. Q uais são as medidas que vai se tomar para interferir nisso, varia, as pessoas têm as opiniões delas, mas não se pode não falar disso.

As disputas entrea diversidadeea inclusão social estão em andamento. A lei que torna obrigatória a implementação de cotas em todas as universidadesfederais brasileiras está em votação no Congresso brasileiro. A predominância da inclusão social éclara: as cotas beneficiarão os estudantes negrose brancos de escolas públicas cujas famílias tenham uma renda determinada. N o entanto, cada estado terá de assegurar quea distribui ção dessas cotas seja representativa de seus grupos raciais.

A maioria dos entrevistados, incluindo osque demonstraram maior apoio à diversidade, considera esse cenário uma vitória mesmo que parcial, uma vez que o Brasil está sendo forçado a lidar com a questão racial. E não é só isso. Alguns também argumentam que foi a ameaça da adoção de cotas exclusi vamenteraciais que possi bilitou a aceitação do sistema de cotas mais amplo, uma vez que a sua implementação em escolas públicas já havia sido vetada outras vezes. 


\section{África do Sul}

$\mathrm{N}$ a África do Sul, os quadros de capital humano e de reparação são mais freqüentes, em comparação aos de diversidade e inclusão social. 0 debate acerca do capital humano e da reparação ilustra os dilemas atuais que esse país enfrenta para decidir entre reparar as desigualdades do passado e redistribuir recursos, ou dirigir seus esforços para integrar o país à economia globalizada. Embora essas duas metas não estejam necessariamente em conflito, representam duas compreensões distintas de política social, que podem resultar em diferenças de implementação e foco. Por um lado, o quadro interpretativo do capital humano concentra-se em talentos individuais e não prioriza grupos raciais. Por outro, o quadro da reparação parte de um comprometimento moral de redistribuição, necessário para que grupos raciais anteriormente excluídos sejam compensados. Aqui, o conflito principal ocorre entre as abordagens individualista e coletiva. A tensão entre universalismo e particularismo em relação à raça é menos contundente, talvez devido à forte sobreposição entre classe e raça na África do Sul em comparação ao Brasil. No entanto, é possível perceber uma tendência de fortalecimento do quadro de inclusão social.

A ligação entre ação afirmativa e discriminação histórica fica nítida pelo uso do termo "políticas de reparação" para definir as políticas de ações afirmativas que envolvem 0 acesso ao ensino superior: ao aceitar estudantes negros, as universidades brancas estão pagando uma dívida histórica. Como declarou um dos entrevistados quando perguntado por que não utilizava o termo "ação afirmativa" para o acesso à universi dade:

0 termo ação afirmativa tem uma certa conotação negativa. Faz a gente pensar nos muitos anos de implementação nos Estados U nidos e outros lugares, e, mesmo depois de quatro, cinco décadas, as coisas não foram resolvidas. 0 conceito de reparação parece ser mais apropriado se olharmos para os estudantes que estão sendo admitidos, e o termo eqüidade é mais apropriado que ação afirmativa.

$\mathrm{Na}$ C onstituição Sul-Africana de 1996, a legalidade da ação afirmativa, ou discriminação justa, está relacionada à retificação das desigual dades do passado. Como frisou outro entrevistado: "O princípio da discriminação justa na Constituição nos permite, para reparar as iniqüidades do passado, admitir esses estudantes [estudantes negros em vez de brancos]". 
O utro conceito central no debate sobre ação afirmativa é "transformação". Transformação tornou-se a palavra de ordem nos debates políticos nesse país e, basicamente, significa romper as estruturas do apartheid. Por exemplo, alguns entrevistados argumentam que o sistema judicial não é confiável porque não foi transformado. E as universidades, se transformaram? Aquelas historicamente brancas, em particular, foram acusadas de não se ter transformado o bastante, por ainda serem dirigidas por homens brancos. Além disso, a cultura institucional tampouco teria mudado.

Contudo, expressões e termos como "corrigir as coisas" ou "transformação" podem se referir não apenas ao apartheid do passado, mas também a outros desafios mais atuais. As sólidas fronteiras culturais entre os grupos raciais (reforçadas por uma forte segregação residencial e baixas taxas de casamentos inter-raciais) ea necessidade de incluir os africanos sem provocar a saída dos brancos criaram o ideal da África do Sul como o "país do arco-íris".

Ao contrário dos entrevistados brasileiros, os sul-africanos compartilham o pressuposto de que diversidade é um aspecto positivo. Como afirma uma das entrevistadas (branca), quando perguntado se a ação afirmativa era necessária para romper certas prerrogativas de grupo: "Sim, porque se acreditarmos que existe apenas um valor intrínseco na diversidade e um valor intrínseco na representação de diferentes setores da nossa nação, raça, classe etc., então estaremos perdendo algo se não o fizermos".

Contudo, se de um lado a diversidade é uma contribuição obviamente positiva, de outro, parece ter um significado estreito, próximo ao da reparação: 0 da representação estatística de certos setores da sociedade. Apenas um entrevistado apresentou a diversidade no sentido norte-americano clássico: como estudantes de diversas origens levando perspectivas singulares para a universidade e enriquecen do o debate acadêmico.

O utra evidência dessa falta de centralidade da diversidade, levantada por um dos entrevistados, é a de que, embora as relações entre raças sejam centrais às políticas sociais na África do Sul, elas não são tão debatidas na academia como questões étnicas ou culturais. Cursos sobre relações raciais e étnicas ainda são raros, mesmo nos departamentos de sociologia.

U ma razão para essa ausência de argumentos pautados na diversidade é o fato de esse conceito estar intrinsecamente ligado às idéias de minorias e de multiculturalismo norte-americanas. $\mathrm{N}$ o entanto, enquanto as minorias nos Estados U nidos são oprimidas, na África do Sul elas são opressoras. Logo, o argumento do multiculturalismo na África do Sul é comumente 
associado à defesa da cultura africânder, por exemplo nos debates sobre a necessidade de preservar as universidades e as tradições africânderes (cf. Giliomee, 1998).

Além disso, parece haver a compreensão de que a diversidade não é suficiente em um país em que a maioria da população é parte do grupo dos desfavorecidos. Segundo um dos entrevistados: "Porque agora [após o fim do apartheid] ficou, de um lado, maisfácil alcançar a diversidade no sentido norte-americano ecultural, mas, de outro, ficou maisfácil excluir os alunos em termos sociais".

Essa observação está diretamente associada ao emergente quadro da inclusão social. 0 argumento é de que na África do Sul a transformação real não é apenas superar divisões raciais e criar o "país do arco-íris", mas também reduzir as desigualdades de classe. $\mathrm{H}$ á também um debate cada vez maior sobre as desigualdades sociais versus raciais. Durante 0 apartheid, raça e classe estavam tão correlacionadas que não haveria nenhuma diferença efetiva entre uma política racial e outra social. Essa forte correlação é resultado de décadas do regime de apartheid, que excluiu os negros das oportunidades educacionais e de emprego, e segregou-os nas chamadas townships.

No entanto, como os negros formam uma maioria, ainda que a classe média negra seja minoritária em relação à população negra, ela representa uma porcentagem alta da classe média como um todo. Esse crescimento permitiu que muitas universidades atingissem as suas metas raciais sem incluir estudantes de grupos desfavorecidos. Apenas dez anos após o fim do apartheid, al guns estudantes negros já têm condições de freqüentar escolas de qualidade e seus pais ocupam cargos de importância no governo. Segundo alguns entrevistados, isso resultou ironicamente na promoção da inclusão racial sem inclusão social.

0 que ouvimos os estudantes negros da classe trabal hadora dizer é que os maiores obstáculos sociais que enfrentam não são tanto os estudantes brancos, mas os negros das classes média e alta. Afirmo isso baseado em relatórios de pesquisas com estudantes. Eu não sei qual é o alcance desse dado, mas as pessoas estão se sentindo muito desconfortáveis. Então, temos estudantes de origem africana e da classe trabal hadora sendo atormentados por causa dos seus sotaques, são motivo de chacota e discriminação. É um fenômeno novo que acontece aqui.

Eles [os estudantes] são ricos; há muitos jovens ricos neste campus, brancos e negros. Então, essas diferenças de classe estão eliminando alguns dos problemas 
23. As escolas "modelo C" eram predominantemente brancas logo apóso fim do apartheid. Eram escolas historicamente exclusivas para brancos que, com a transição, permaneceram como escolaspúblicas, mascom contribuições financeiras das famílias e, portanto, com receitas de administração mai oresqueasescolaspúblicascomuns. $0 \mathrm{~s}$ estudantes negros freqüentavam asescolas do DET (D epartment of Education and Training). raciais, embora ainda haja muita mistura de classes no campus. D e forma geral, eu diria que a maior porção de estudantes negros africanos no campus é prove niente de famílias razoavelmente ricas. Podemos afirmar isso por causa dos perfis de auxílio financeiro, entre outros, e também pelas escolas que eram brancas anteriormente, as ex-modelo $C$. Esse é o perfil dominante. 0 número de exestudantes das DET [sistema de ensino básico desfavorecido do apartheid] de todas as classificações negras é baixo ${ }^{23}$.

Estudos mostram que, desde o final do regime do apartheid, as desigualdades entre os grupos raciais têm diminuído, ao passo que as desigualdades internas aos grupos raciais têm aumentado (cf. Seekings e N atrass, 2002; Van den Bergue eL ouw, 2003). Assim, se de um lado os defensores da ação afirmativa argumentam que a lacuna racial representa a principal causa da desigualdade, de outro, os críticos contra-argumentam que as políticas raciais só beneficiarão uma minoria de negros e manterão a alta desigual dade socioeconômica quecaracteriza a África do Sul. Elestambém sustentam que o país deve abandonar as classificações raciais que caracterizavam 0 apartheid e dar prioridade à classe, e não à raça. São essas as pessoas que pressionam por uma abordagem universalista em vez de particularista, e que seja voltada para os estudantes da classe trabal hadora e das zonas rurais.

Como a maioria das pessoas da classe trabalhadora é negra e a maioria dos negros, com exceção dos indianos, talvez, pertence à classe trabal hadora, esse debate se torna menos polêmico na África do Sul do que no Brasil. Além disso, os cientistas sociais da África do Sul tradicionalmente compreendem as desigual dades raciais e étnicas como produtos da exploração de classe (baseados em uma tradição marxista arraigada no meio acadêmico). Contudo, essa posição está amplamente associada ao grupo de brancos liberais, quetendem a negar o problema da discriminação racial como separado da desigualdadesocioeconômica. Um dos entrevistados (indiano) apontou algumas insuficiências nessa posição: em primeiro lugar, não há dados sólidos para estabelecer quem são os estudantes da classe trabalhadora; em segundo lugar, não há dados confiáveis que provem que os negros estejam realmente recuperando o terreno em relação aos brancos; e, finalmente, o país estaria preparado para interromper as discussões sobre raça?

Você tem, e eu considero isso uma infelicidade, muitos acadêmicos brancos utilizando inúmeros pressupostos sobre diversas coisas, e que às vezes baseiam-se em preconceitos e não em fatos reis [... ]. Eu acredito que a maioria dos nossos estu- 
dantes [negros], por causa da estrutura de raça e classe da sociedade sul-africana, ainda é de origem relativamente pobre. A classe média negra não cresceu tão rápido como as pessoas tendem a supor pelo que lêem nos jornais. $\mathrm{N}$ em todos os ne gros se tornaram milionários. Sim, a classe média está crescendo. E, sim, as crianças começarão a ir muito mais para escolas privadas e ex-modelo C , mas não acho que estejamos num ponto em que esses estudantes de origem privilegiada estejam expulsando as crianças negras provenientes de famílias de áreas rurais e da classe trabalhadora.

Ao contrário da diversidade e da inclusão social, o quadro do capital humano é tão amplamente aceito quanto o de reparação. Ele foca a necessidade de ação afirmativa em termos de mercado de trabal ho e produtividade acadêmica. No caso da África do Sul, a grande maioria dos entrevistados associou a ação afirmativa à necessi dade de crescimento econômico. A explicação é que 0 apartheid negou oportunidades a muitos jovens de talento e, por causa disso, solapou o crescimento econômico. Portanto, o acesso deve se concentrar nas carreiras que possam contribuir para o crescimento econômico, normalmente as áreas de ciências e engenharia.

0 quadro do capital humano geralmente foca o "desperdício" de jovens de talento em razão da discriminação do passado ou do presente, mas às vezes usa a conotação da geração de profissionais comprometidos com áreas desfavorecidas (cinco entre 21). Exemplo por excelência dessa abordagem são as faculdades de medicina, que começaram a priorizar a seleção de estudantes que falam idiomas africanos e que são de origem rural, particularmente atingidas pela epidemia de HIV. Logo, em algumas universidades a seleção desses estudantes começou a ser feita não ape nas com base nos resultados do exame de finalização do ensino médio ( 0 $M$ atriculation, ou $M$ atric, exame equivalente ao nosso vestibular), mas também em cartas de recomendação e em um questionário biográfico, no qual os estudantes devem demonstrar motivação, comprometimento social e consciência política.

Contudo, na maioria dos casos, segundo o quadro do capital humano, 0 foco das políticas de ações afirmativas voltou-se para a identificação dos bons estudantes, mas que não estão bem preparados ou foram prejudicados pelo fato de não terem o inglês como idioma nativo (embora não esteja clara a definição de "bom estudante" e nem quais talentos são desejáveis). Segundo um dos entrevistados, quando perguntado se a universidade deve ria expandir-se para aceitar mais estudantes: 
Essa é uma pergunta ainda sem resposta porque não se trata apenas de ter mais estudantes, mas de ter estudantes capazes de ser bem-sucedidos, trata-se, em outras palavras, de ter bons estudantes. C laramente é uma questão de se ter mais bons estudantes. Eu concordaria com a afirmação se ela fosse sobre bons estudantes. D ito isto, uma universidade como a [...] deve prestar atenção à qualidade porque, veja, onde mais se produz esse conhecimento de ponta, onde mais se utiliza pesquisas nos âmbitos nacional e internacional, e produz conhecimento com base no que há de mais avançado? Esses fatores se concentram muito nos mecanismos de avaliação e nas maneiras de selecionar estudantes com al to potencial.

Ao analisar os documentos oficiais, fica claro também que está em processo uma mudançana abordagem do governo nacional com relação às políticas de ensino superior. $N$ as primeiras versões dos documentos oficiais, escritos entre 1994 e 1997, houve uma forte referência à reparação e à massificação (no sentido deaumentar o número deestudantesno sistemade ensino universitário). Jáno documento de 1997, a ênfasefoi desviada para a eficiência da universidade: graduação de mais estudantes, publicação de artigos em periódicos internacionais e criação de parcerias com o setor privado. Recentemente, o departamento de educação decidiu reduzir o número de matrículas na universidade, uma decisão que surpreende, especialmente em um país com taxa bruta de matrículas de $17 \%$ (contra $70 \%$ nos Estados Unidos e $20 \%$ no Brasil). Essa mudança foi percebida por pesquisadores não só da área do ensino superior, mas também de outrasáreas, como política macroeconômica, na qual a ênfase na redistribuição foi substituída pela ênfase no crescimento econômico (cf. K raak, 2004).

Em um estudo qualitativo sobre as elites sul-africanas, os autores revelaram que a elite econômica (na maior parte branca) acredita que, depois do final do apartheid, a desigualdade na África do Sul vem sendo rapidamente superada (cf. Reis e M oore, 2005). As políticas de ações afirmativas contribuíram para que isso acontecesse, porém, na opinião dessa elite, elas devem ser desativadas em breve. Com argumentos semelhantes aos do caso norteamericano, muitos brancos reclamam da discriminação inversa. Ao enfatizar os talentos individuais, o "capital humano" torna as políticas de ações afirmativas mais aceitáveis a essas elites de maioria branca.

O utra menção recorrente é a necessidade de preservar a qualidade das instituições. Parece haver uma tensão entre reparação e qualidade no discurso de muitos administradores. A meta dessas universidades, especialmente as historicamente brancas, é, como foi levantado por um dos entre- 
vistados, ser iguais a "O xford, C ambridge ou H arvard". Essas universidades acreditam no próprio potencial e querem participar de forma influente no mundo acadêmico internacional, o queé possível agora, uma vez que as sanções contra 0 apartheid foram removidas.

Isso não significa que as universidades não estejam cientes das desigualdades ao seu redor, como mostra o debate sobre a reparação. Porém, os entrevistados sul-africanos são mais conscientes do que os brasileiros com relação à ironia de uma instituição de elite em uma sociedade tão desigual:

A missão desta universidade será sempre a de avaliar e encontrar jovens com habilidades específicas, provenientes da classe trabalhadora, e transformá-los em cientistas de nível internacional. Agora, se isso pode ou não ser considerado elitista, é uma pergunta interessante. Eu reformularia o problema da seguinte forma: como uma universidade como esta deve abordar as questões de desenvolvimento social e econômico [... ] o que significa para uma universidade como a [...], que aspira alcançar o nível de uma $\mathrm{H}$ arvard ou de uma $\mathrm{C}$ ambridge, ou outra dessa categoria, mas que está situada sobre uma "fal ha geológica" de política e na extrema exclusão social [... ]. Eu acho que as universidades são apropriadamente elitistas em alguns aspectos. Q uer dizer, as universidades sempre discriminaram. D iscriminam a favor das pessoas que, segundo a avaliação das próprias universidades, têm capacidade de ser bem-sucedidas. D iscriminam com base na percepção que têm da inteligência, capacidade e compromisso dessas pessoas selecionadas. Agora, se você diz que $H$ arvard só admite os melhores $2 \%$ das pessoas que se candidatam e a [...] só admite os melhores $5 \%$, então, nesse sentido, somos elitistas. Logo, a nossa posição pública será sempre a de afirmar a nossa flexibilidade nas admissões, mas somos muito rígidos quanto à manutenção dos padrões da graduação. A minha posição aberta, mas necessariamente particular, seria responder "sim" [devemos nos manter altamente seletivos]. Às vezes acertaremos, às vezes, não.

Em resumo, as universidades sul-africanas definem ação afirmativa de duas formas muito distintas. D e um lado, enfatizam a necessidade de reparar a discriminação do passado. De outro, querem identificar estudantes talentosos que as promovam a uma posição de igualdade no mercado acadêmico global. As disputas entre esses dois quadros também estão em andamento e, dependendo do resultado, a África do Sul irá implementar políticas de ações afirmativas muito diferentes. D e um lado, os desenvolvimentos mais recentes da reforma do ensino superior indicam que as abordagens 
baseadas no capital humano estão se tornando mais fortes. Como os financiamentos acadêmicos são cada vez mais associados à produtividade dos estudantes, as instituições são obrigadas a depender de talentos individuais em vez de adotar abordagens de cunho coletivo. D e outro lado, a força do argumento da reparação e a crescente desigual dade inter-racial pode abrir espaço para o quadro da inclusão social, uma vez que este último permite uma abordagem menos racializada e, ao mesmo tempo, de reparação coletiva. As propostas feitas recentemente por universidades, voltadas para a seleção a partir das escolas de ensino médio e não da origem étnico-racial, apontam para esse tipo de solução.

Resumo e conclusão

Por serem países com histórias de relações raciais completamente diferentes, surpreende o fato de Brasil eÁfrica do Sul estarem implementando políticas semelhantes para combater as desigualdades raciais. Essas semeIhanças normalmentetêm sido explicadas pelos argumentos da difusão edo isomorfismo, seja como evolução dos direitos humanos, seja como violência simbólica. Contudo, as explicações ignoram diferenças importantes entre as políticas, que não possuem significados iguais nem têm as mesmas metas e conseqüências em contextos tão diferentes.

N este artigo, argumento que os debates criados pela implementação das políticas, o que chamei de batalhas de enquadramento, são centrais para a compreensão dos processos de difusão. A revelação empírica de maior impacto decorrente dessa comparação éa de que as políticas de ações afirmativas podem ser interpretadas por vários quadros, que criam tensões diferentes, dependendo do contexto. As políticas raciais (perspectiva particularista do mundo social) parecem ser objeto deuma disputa menosintensa na África do Sul do queno Brasil, um paísmais apegado a sua imagem de democraciaracial. Aspolíticas deinclusão voltadas para grupos, por outro lado, parecem mais aceitas nas universidades brasileiras do que nas instituições sul-africanas, que almejam ingressar no mundo acadêmico globalizado e opõem qualidadee inclusão social. As disputas são definidas sobretudo pela recepção dessas políticas a partir de diferentes val ores nacionais cognitivose normativos relacionados a raça, mas também pelas diferenças na organização socioeconômica e institucional da vida social. C ontudo, esses esquemas culturais e estruturas não determinam os resultados das disputas. Ao contrário, preparam o cenário para as batalhas de enquadramento, cujas dinâ- 
micas podem transformar essas mesmas estruturas. Por exemplo, o quadro da diversidade promoveu a questão das identidades negras no Brasil, enquanto os quadros da inclusão social e do capital humano transformaram a perspectiva da reparação na África do Sul.

A principal contribuição do foco nas batalhas deenquadramento éa possibilidade de analisar a implementação depolíticas como um processo dinâmico de disputa entre definições internacionais enacionais, bem como entre os interesses nacionais. Essa natureza dinâmica das disputas evita a compreensão essencialista dos processos de difusão e de recepção. Em vez disso, obriga a considerar a implementação das políticas como um processo dinâmico.

Referências Bibliográficas

Ad AM , Kanya. (1997), "Thepolitics of redress: South African styleaffirmativeaction". The Journal of Modern African Studies, 35: 231-249.

BeCKER, Gary. (1957), The economics of discrimination. Chicago, U niversity of Chicago Press.

BENFORD, Robert. (1993), "Frame disputes within nuclear disarmament movement". Social Forces, 71: 677-701.

BENFORD, Robert \& SN OW , D avid. (2000), "Framing processes and social movements: an overview and assessment". Annual Review of Sociology, 26: 611-639.

Bourdieu, Pierre\& W Acquant, Loïc. (1999), "O n thecunning of imperial ist reason”. Theory, Culture, and Society, 16: 41-58.

Campbell, John L. (2002), "Ideas, politics, and public policy". Annual Review of Sociology, 28: 21-38.

DiMaggio, Paul \& Powell, William. (1991), "The new institutionalism in organizational analysis". Chicago, University of Chicago Press.

D о ввIN, Frank. (1994), Forging industrial policy. N ova York, Cambridge University Press.

D urkieim, E. (1988), As regras do método sociológico. São Paulo, M artins Fontes.

Feree, M.; Gamson, W. A.; Gerhards, J. \& Rucht, D. (2002), Shaping abortion discourse: democracy and the public sphere in Germany and the United States. Cambridge, UK, Cambridge University Press.

Friedman, Steve. (1996), "South Africa's pacted transition". In: Friedman, S. \& Villiers, R. D. (eds.), Comparing Brazil and South Africa: two transitional states in political and economic perspective. Johannesburg, ZA, Centre for Policy Studies, pp. 45-68. 
Fry, Peter. (2000), "Cultures of difference: the aftermath of Portuguese and British colonial policies in Southern Africa". Social Anthropology, 8: 117-144. . (2005), A persistência da raça: ensaios antropológicos sobre o Brasil e a África Austral. Rio de Janeiro, Civilização Brasileira.

Fry, Peter \& M AGgIE, Yvonne. (2002), "A reserva de vagas para negros nas universidades brasileiras". Estudos Avançados, 18: 67-80.

GILIO meE, H ermann. (1998), "T he majority, minorities and ex-nationalities in South Africa and the proposed cultural commission". In: Seminar Report: the constitutional protection of multiculturalism. Johannesburg, SA, Konrad-AdenauerStiftung, pp. 37-44.

Globo. (2006a), “D ocumento contrário à lei de cotas e ao Estatuto de Igualdade Racial". O Globo. Rio de Janeiro, 30 jun. . (2006b), "M anifesto a favor da lei de cotas e do Estatuto de I gualdade Racial". 0 Globo. Rio de Janeiro, 5 jul.

Guillebeau, Christopher. (1999), "Affirmative action in a global perspective: the cases of South Africa and Brazil". Sociological Spectrum, 19: 443-465.

G UILLEN , M auroF. (2001), Thelimitsof convergence: gl obalization and organizational changein Argentina, South K orea, and Spain. Princeton, N J , Princeton U niversity Press.

H am ilton, Charles; Huntley, Lynn; Alexander, N eville; Guimarães, Antonio Sérgio Alfredo \& JAM ES, W ilmot. (2001), Beyond racism: raceand inequality in Brazil, South Africa and the U nited States. Londres, Lynn Rienner.

H ollin Ger, D avid A. (1995), Postethnic America: beyond multiculturalism. N ova York, BasicB ooks.

H tun, M ala. (2004), "From 'racial democracy' to affirmative action: changing State policy on race in Brazil". Latin American Research Review, 39 (1): 60-89.

J ACOBSEN, J. K. (1995), "M uchado about ideas: the cognitive factors in economic policy". World Polit, 47: 283-310.

KraAk, Andre. (2004), "D iscursive tensions in South African higher education, 1990 to 2002". Journal of Studies in International Education, 8: 244-281.

LAM ONT, M ichele \& BAIL, Christopher. (no prelo), "Bridging boundaries: the equalization strategies of stigamatized ethno-racial groups compared". RevueEuropéene des M igrations Internationales, Special Edition.

Lam Ont, M ichele \& TheVen ot, Laurent. (2000), "Rethinkking comparative cultural sociology: polities and repertoires of evaluation in France and the United States". Cambridge, Cambridge University Press.

LIN D SAY, Beverly. (1997), "Toward conceptual, policy, and programmatic frameworks of affirmative action in South African universities". Journal of N egro Education, 66: $522-538$. 
M ABO KELA, Reitumetse O bakeng. (2000), Voices of conflict: desegregating South African universities. N ova York, RoutledgeFalmer.

M ARX, Anthony. (1998), M aking race and nation: a comparison of South Africa, the United States and Brazil. Cambridge, Cambridge University Press.

Meyer, John W.; Boli, John; Thomas, George M . \& Ramirez, Francisco O . (1997), "World society and the N ation-State". American Journal of Sociology, 103: 144181.

M ittlem An , J. H . (2000), The globalization syndrome: transformation and resistance. Princeton, Princeton University Press.

PARIKH, Sunita. (1997), The politics of preference: democratic institutionsand affirmative action in the U nited States and India. Ann Arbor, University of M ichigan Press.

PerIA, M ichelle. (2004), "Ação afirmativa: um estudo sobre a reserva de vagas para negros nas universidades públicas brasileiras: o caso do estado do Rio de Janeiro". Social Anthropology. Rio de Janeiro, Museu Nacional/U FRJ.

Pıovesan, Flavia. (2006), O rdem jurídica e igualdade étnico-racial. São Paulo, Prol.

ReIs, Elisa \& M OoRE, M ick (eds.). (2005), Elite perceptions of poverty \& inequality. Londres, Zed Books.

Ribeiro, Luiz Fernando Ferreira da Rosa. (1994), "Comparing Brazil and South Africa: a comment". South African Sociological Review, 7: 63-66. . (1996), "'Apartheid' and 'democracia racial': South Africa and Brazil in contrast". Utrecht. D octoral Thesis Anthropology. U niverseit U trecht.

SabBaGH, D aniel. (2004), "Affirmative action policies: and international perspective. U nited N ations D evelopment Program". United N ations D evelopment Program, pp. 50.

SATO, Kyoko. (2004), "M edia framing of genetically modified foods in the U nited States, France and Japan". Trabal ho apresentado na American Sociological Association, na mesa "Section on Sociology of Culture Refereed Roundtables", 4 ago. Schmitter, Phillippe. (1996), "Concluding remarks". In: Friedman, S. \& Villiers, R. D . (eds.), Poverty and social inequality: profile and policy options.J ohannesburg, ZA, Centre for Policy Studies, pp. 357-362.

Seekings, Jeremy \& N atrass, Nicoli. (2002), "Class, distribution and redistribution in post-apartheid South Africa". Transformation, 50: 1-30.

SeIdmAn, Gay. (1994), M anufacturing militance: workers' movements in Brazil and South Africa, 1970-1985. Berkeley, University of California Press.

SkrentNy, John D. (1996), The ironies of affirmative action. Chicago, University of Chicago Press.

SowelL, Thomas. (1990), Preferential policies: an international perspective. N ova York, W. M orrow. 
. (2004), Affirmative action around the world. New Haven, Yale University Press.

Strang, D avid \& Chang, Patricia (1993), "The international labor organization and the Welfare State: institutional effects on national Welfare Spending, 196080". International Organization, 47: 235-262.

Subotzky, George. (2003), "South Africa”. In: Teferra, D. \& Altbach, P. (eds.), African higher education: an international reference handbook,. Bloomington, IN , Indiana University Press, pp. 545-562.

SWIDLER, Ann. (1986), "Culture in action: symbols and strategies". American Sociological Review, 20: 305-309.

Telles, Edward Eric. (2004), Race in another America: the significance of skin color in Brazil. Princeton, NJ, Princeton University Press.

Telles, Edward \& Bailey, Stanley. (2002), "Políticas contra o racismo e opinião pública: comparações entre Brasil e Estados U nidos". O pinião Pública, 8: 30-39. United Nations. (2004), "Human development index report". United $N$ ations, N ova York, NY.

Van den Bergue, Servaas \& Louw, M egan. (2003), "Changing patterns of South African income distribution: towards time series estimates of distribution and poverty". In: Conference of the Economic Society of South Africa, Stellembosch.

W AN G, Bee Lan Chan. (1983), "Positive discrimination in education: a comparative investigation of its bases, forms and outcomes". Comparative Education Review, 27: 191-203.

W Eber, M ax. (1946), "T he social psychology of the world religions". In: GERTH, H. $\&$ M ILls, C. (eds.), From M ax Weber. N ova York, Oxford University Press. W ILLIAM SON, Jeffrey G. (1996), "Globalization, convergence, and history". Journal of Economic H istory, 56: 277-306.

W otipka, Christine \& RamiRez, Francisco O . (2003), "World society and human rights: an event history analysis of the convention on the elimination of all forms of discrimination against women". Annual meeting of the American Sociological Association, Atlanta.

\section{Resumo}

Ações afirmativas no Brasil e na África do Sul

N este artigo, comparo as políticas de ações afirmativas no ensino superior no Brasil e na África do Sul. Algumas perguntas orientam essa comparação: por que países com histórias e estruturas raciais completamente diferentes estão implementando políticas semel hantes para lidar com a desigual dade entre as raças? M ais especificamente, por que o Brasil, um país de fronteiras raciais menos rígidas do que a África do Sul, im- 
plantou uma forma mais radical de ação afirmativa? Como as diferentes compreensões nacionais do que é raça influenciam a adoção e as discussões sobre as ações afirmativas dirigidas às questões raciais? Por fim, e talvez mais importante, como essas políticas "importadas" influenciam os debates raciais no Brasil e na África do Sul? Palavras-chave: África do Sul e Brasil; Estudos comparativos; Q uadros interpretativos; Ação afirmativa; Relações étnico-raciais.

\section{Abstract}

Affirmative actions in Brazil and South Africa

In this paper I compare race-targeted affirmative action policies in higher education in Brazil and South Africa. A few questions guide this comparison. Why are countries with completely different racial structures and histories currently implementing similar policies to address racial inequality? And, more specifically, why did Brazil - a country with historically less rigid racial boundaries than South Africa - implement a more radical form of affirmative action than South Africa? $\mathrm{H}$ ow do these different national understandings of race influence the implementation and debates about racetargeted affirmative action? And, maybe more importantly, how do these "imported" policies influence the above mentioned national contexts? Keywords: South Africa and Brazil; Comparative studies; Frames; Affirmative action; Ethnic-racial relations.

Graziella M oraes Dias da Silva é doutoranda em sociologia na Universidade de $\mathrm{H}$ arvard e estudante associada do Programa Multidisciplinar de Estudos sobre D esigual dade na Escola de Governo John F. Kennedy, na mesma universidade. E-mail: silva@fas.har vard.edu. 